\title{
Situating occupation in social relations of power: Occupational possibilities, ageism and the retirement 'choice'
}

\section{Debbie Laliberte Rudman, PhD., OT Reg (ON)}

Associate Professor. School of Occupational Therapy, and Graduate programme in Health and Rehabiliation Sciences (Occupational Science field), The University of Western Ontario, Canada

Introduction: Research attending to social relations of power can enhance understanding of the mechanisms through which occupational injustices occur and inform socially transformative practice. This study explored how power operates through ageism in ways that shape what people come to take for granted regarding occupation in relation to age, and what occupations are supported through sociopolitical conditions.

Methods: Narratives were collected using a two-stage interview process with 17 retired Canadians. A critical narrative analysis approach was employed to examine how these narratives revealed the complex ways occupations are negotiated within broader discourses and age relations.

Findings: Ageism mattered for how and when individuals came to retire and for occupational possibilities in the realm of work. Informants conveyed experiences of being marginalised, displaced and disempowered in the work force and, at times, internalised ageist discourses to make sense of when and how they came to retire.

Conclusion: Within the study context, social relations of power related to age influenced occupational possibilities for work and bounded retirement 'choices'. A focus on power in relation to occupation as it intersects with a variety of social markers can provide a nexus to inter-connect socially transformative work in occupational therapy and occupational science, advancing the shared intent of promoting human flourishing through occupation.

Key words: Narrative, discourse, occupational injustice, later life

\section{INTRODUCTION}

There has been a sustained critique of the pervasiveness of an individualistic approach to the conceptualisation of occupation over almost the past 10 years ${ }^{1,2,3}$. In turn, scholars have incorporated a range of social perspectives to study 'occupation as situated'; that is, as always shaped within and contributing to the shaping of social, cultural, political, and economic contexts ${ }^{4}$. Such work has lead to the expansion of concepts, such as occupational identity and occupational choice, in ways that have de-centered the individual and raised awareness of the dialectical transactions of individuals,

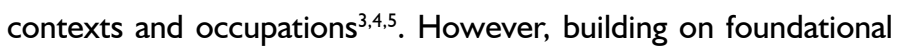
work related to occupational justice and the political nature of occupation $^{6,7}$, there has been increasing recognition of the need to employ theoretical and methodological approaches that address social relations of power $8,9,10$. To date, work addressing the situated nature of occupation has tended to neglect how social relations of power are enacted in ways that create and perpetuate situations of discrimination, marginalisation and oppression ${ }^{11,12,13,14}$. Attention to social relations of power is essential if the study of occupation is to critically raise awareness of the mechanisms through which oc- 
cupational injustices are enacted and, in turn, inform practice aimed at transforming socio-political practices, systems and structures to create more occupationally just conditions ${ }^{15,16,17,18}$.

This paper addresses the embeddedness of occupation within social relations of power tied to age. It aims to both illustrate a methodological approach that can be employed to critically examine the influences of discourse on lived experience and occupational possibilities, and also the potential understandings of occupation that can evolve from such work. Drawing on narrative data collected from retired individuals in a Canadian city, the analysis critically addresses how ageism, as an ideology and form of discrimination based in social relations of power, bounded occupational possibilities and choices in the work to retirement transition. In concert with the emerging body of work integrating critical social science frameworks to examine how social relations of power tied to race, gender, citizenship status, and other attributes shape possibilities for occupations, this paper aims to further raise awareness of the need to attend to social relations of power in occupation-centred research and practice in order to form and sustain contexts that enable human flourishing and dignity through occupation.

\section{Politicising occupation: Occupation and social relations of power}

Several authors have pointed to the importance of politicising occupation; that is, placing occupation within broad relations of power to raise awareness of, and inform actions to address, how such relations shape and perpetuate occupational inequities ${ }^{3,4,8,9,18,19}$. One of the first concepts offered up as a means to centre issues of power was that of occupational injustice ${ }^{7}$. The conceptualisation of occupational injustices as “... an outcome of social policies and other forms of governance that structure how power is exerted to restrict participation in the everyday occupations of populations and individuals" $20: 58$ provided a foundation for research and practice that addresses socio-political forces that lead to occupational deprivation, alienation, marginalisation and imbalance ${ }^{20}$. Moreover, a growing number of authors have pointed to the long history of politically informed occupation-based practice aimed at social transformation in the southern hemisphere or 'peripheral' countries, emphasising the need to incorporate knowledges and practices generated outside a Western epistemological frame $e^{6,10,13,15}$. For example, in outlining a political practice of occupational therapy, Pollard, Kronenberg and Sakellariou proposed that occupational therapy be conceptualised as a political endeavour in which access to meaningful occupation is viewed as a right ${ }^{6}$. Galheigo also called for focussing on occupation as a human right, fostering of political consciousness amongst occupational therapists, and working against the transformation of ethical and political problems into biomedical and technical issues ${ }^{10}$.

In concert with this growing awareness of the political nature of occupation, occupational therapists have been challenged to further take up an approach to practice that addresses abuses of the right to occupation ${ }^{21}$. In parallel, within occupational science, there have been calls to develop critically informed approaches which address how social relations of power shape occupational injustices at individual, collective and societal levels ${ }^{17,18}$. This focus on power and occupation may thus provide a nexus to inter-connect socially transformative work occurring in occupational therapy and occupational science across professional and national 'borders', providing a space for collaboration aimed at a shared intent of advancing practice that promotes human flourishing via the transformation of socio-political practices, systems and structures that shape and perpetuate occupational injustices ${ }^{18,22}$.

\section{Occupation and social power: Research exemplars}

Although work attending to power within the study of occupation has been identified as in need of development, examples exist which demonstrate its potential contributions ${ }^{16}$. For example, Beagan and Etowa studied the impact of everyday racism on the occupations of African American women in Nova Scotia, Canada ${ }^{2}$. Drawing upon the work of Essed, they defined racism as inherently connected to power, specifically, as “... taken-for-granted ways of being that unwittingly enact social power relations, privileging some and marginalising others" 12:292. Using mixed methods with a sample of 50 women aged 40 to 65 , Beagan and Etowa demonstrated how racism, as experienced, feared and anticipated, impacted a wide range of occupations carried out by the women in a diversity of places. These authors challenged the notion that occupational choice is individually determined by attending to how racism shaped both what occupations were done and where they were done. These authors called for further attention within research and occupational therapy practice to the implicit, taken-for-granted ways racism is enacted through everyday occupations in ways that "... uphold social relations of power and oppression"12:286.

Work by Galvaan done within the context of a marginalised community in Cape Town, South Africa also attended to social relations of power related to race and raised critical questions about individualised notions of occupational 'choice's. Galvaan conducted a critical enthnography with seven young adolescents living in a 'coloured' residential area. Her analysis highlights the intersecting socio-economic and political influences that contributed to the adolescents making hegemonic occupational 'choices' within the constraints of habitus and contextual conditions which maintained historically predicated patterns and perpetuated occupational injustices. Galvaan asserted that "... normative standardisation of low expectations for occupational engagement" $3: 160$ may be a key feature of how occupational marginalisation is perpetuated. At the practice level, she argued that promoting different patterns of occupational choices needs to extend beyond providing more opportunities to address the political and socio-economic factors that establish patterns of choice.

As another example of work on occupation that has explicitly brought social power to the fore, Ramugondo expanded the lens beyond the occupations of individuals to consider how geographical, historical, social, political and economic contexts shape the cocreation and negotiation of play across and between generations ${ }^{23}$. Using a case study approach with a Venda family in South Africa, Ramugondo addressed power within the context of globalisation by pointing to how families in "... the periphery of a western-led model of globalisation"23:336 increasingly have diminishing possibilities for shaping both play across generations and their unfolding collective narratives. Out of this research, Ramugondo proposed the concept of occupational consciousness, a concept that directs attention to the dynamics of social power and calls for practices that "... increase people's awareness of socio-economic and political conditions that explain their live realities, so that they can be active participants in their own unfolding occupational narratives"23:337.

These studies, as well as other recent examples ${ }^{1,24,25}$, demonstrate the potential for critically-informed research to highlight how occupation is a means through which marginalisation is shaped and perpetuated, as well as how various forms of discrimination occur within and through everyday occupation. This study adds to this emerging body of work by considering how ageism shapes occupational possibilities in relation to work and retirement.

\section{Ageism and the shaping of occupational possibilities}

According to Butler's foundational definition “... ageism can be seen as a process of systematic stereotyping of and discrimination against people because they are old"26:243. Ageism encompasses inter-connected ideological dimensions, such as negative stereotypes, beliefs and attitudes related to age, and behavioural dimensions, encompassing discriminatory behaviours that exclude and disadvantage people on the basis of age ${ }^{27}$. In addition, ageism can operate at various levels. For example, within everyday social relations, the appearance of bodily age can lead to experiences of stigma and social exclusion. At the individual level, ageism can shape how one thinks about what older adults are capable of doing and should do ${ }^{28}$. At the level of social practices and institutional systems, age can be taken up in ways that discriminate against those who are classified as old ${ }^{29}$.

Even though formal institutional policies have been enacted in many national and international contexts to act against ageism, 
ageism continues to be embedded within the societal organization of age relations so that "... different age groups gain identities and power in relation to one another"28:8. Emphasising the implicit nature of ageism, Calasanti has pointed to how it has become "... embedded in institutions such that simply following 'normal' procedures or behaving in taken-for-granted ways can exclude old people"28:8. For example, several authors have emphasised that ways in which negative beliefs about the characteristic of aging persons as workers (for instance, as less flexible, efficient and trainable) are taken up to justify discriminatory practices that marginalise older workers ${ }^{29,30,31}$. Thus, practices, systems and policies, predicated on social relations of power tied to age, often become taken-forgranted and unquestioned, obscuring ageist assumptions and practices $^{32}$. In turn, research must move beyond individual instances of ageism to attend to ageist structures and issues of power to raise awareness of the multifarious ways “... oppressed older people are subject to marginalisation, violence, powerlessness, exploitation, and cultural imperialism, all historically and geographically situated in sites of ageism such as families and households, government agencies, health care systems and waged labour markets"27:113.

Within this study, ageism is conceptualised as embedded with social relations of power in ways that shape occupational possibilities. The concept of occupational possibilities, grounded within a Foucauldian sense of power as productive, refers to ways and types of doing that come to be viewed within a specific socio-historical context as possible and ideal and that, in turn, are supported and made available through social systems and structures ${ }^{33}$. Thus, this study firstly explores how power operates through ageism in ways that shape what people come to take for granted as to what they themselves and others can and should do given their age. Secondly this study investigates what occupations are made available to ageing and older adults and what occupations are closed down by various aspects of the relations, systems and structures in which their lives are lived.

Given variations in population ageing across nation states, differential policy responses, and diverse cultural constructions of aging $^{34,35}$ research addressing ageism must be contextualised. The study described in this article was conducted in a medium sized city within Canada. Within this context, as within several other countries belonging to the Organisation of Economic Cooperation in Development (OECD), there has been a massive re-configuration of discourses and policies pertaining to work and retirement since the 1990s partly in response to rising concerns regarding the economic and social implications of population ageing. For example, while retirement and public pensions had come to be viewed as a social right in the postWorld War Two period and early exit from work had been encouraged in the 1970s and 1980s as a means to deal with unemployment and optimise productivity in Canada, the United States and many European nations, there has been a dismantling of both the 'right' to retire and public pension systems as well as a growing focus on ageing citizens working longer and assuming greater responsibility for retirement savings and pensions ${ }^{36}$. More specifically, within the Canadian context, re-configured discourses of 'positive' and 'productive' ageing have been increasingly fore fronted in policy and public texts as a means to promote individual responsibility for proactively managing the health, social and financial 'risks' of ageing ${ }^{37,38}$.

\section{METHODOLOGY AND METHODS}

The data used in this paper are drawn from a broader study employing critical discourse analysis and critical narrative inquiry to examine the contemporary socio-political reconfiguration of retirement. Drawing upon Foucauldian-informed governmental theory ${ }^{39}$, retirement is drawn upon as a terrain of study to examine the re-configuration of occupational possibilities for ageing individuals. Previous publications have focussed primarily on the discursive reconfiguration of retirement in media and policy texts as a means to raise critical awareness of how neoliberal rationality, with its emphases on heightening individual responsibility, privatisation, and market logic, is being taken up in ways that perpetuate occupational inequities in later life ${ }^{40,41,42}$. Within the critical narrative aspect of this study, from which the findings presented below are drawn, I seek to analyse how discourses about age, including ageist ideologies, influence how ageing individuals negotiate and make sense of what they do in preparing for and being in retirement.

From a governmentality perspective, discourses, that is the ways that a phenomenon (such as retirement) is textually, visually and verbally constructed within institutions and texts, are viewed as productive technologies used by those with power to shape the conduct of individuals through enabling and constraining possibilities for being and doing. While not deterministic, the identities and occupations promoted through dominant discourses progressively come to be viewed as normal, natural, ethical, and ideal, thereby bounding identity and occupational possibilities ${ }^{33,43}$. The basic underlying assumption being made about the inter-relationship of discourses and narratives is that the narratives people tell are bounded within the broader discourses to which they have access within a specific social, historical and political context ${ }^{43,44}$. Given that individuals are exposed to a multiplicity of discourses and actively negotiate these within everyday life, narratives provide a means to study the 'in between', that is, how individuals' choices are situated within structural features that enact power by setting boundaries and possibilities, while also acknowledging that individuals actively negotiate their occupations with varying power and resources to do $\mathrm{so}^{43,44}$.

\section{Recruitment and study context}

Following receipt of institutional ethics approval, narratives were elicited with 30 informants who self-identified as preparing for or in retirement. Additional inclusion criteria included being 45 years of age or older, able to participate in an interview in English, and residing in Canada for at least the past 10 years. Recruitment employed various means, including presentations, newspaper advertisements, posters, and snowball sampling. Within this article, data from 17 retired informants ( 12 females, 5 males) are employed given the focus on how people storied their retirement decisionmaking. The mean age of retirement for this sub-sample was 58.6 $(S D=6.1)$, which is reflective of socio-political conditions during the time period in which they retired. During the recessionary periods experienced in Canada in the 1980s and early 1990s many firms encouraged early retirement, that is, prior to the public pensionable age of 65 , through incentive packages ${ }^{27}$. Indeed, 9 of the 17 informants reported receiving an incentive package and retiring prior to age 65 . The majority of the informants were married (10), reported adequate finances (I2), and lived in private homes (I0).

\section{Narrative elicitation}

A two-step narrative interview process was carried out by five individuals, myself and four doctoral students. Each informant participated in two audio-taped interviews, both conducted by the same interviewer. In the first interview, participants received two narrative prompts: i) "I would like you to tell me your story of how you are preparing for your retirement years, including all the events and experiences which are important for you. Start wherever you like", and, ii) "I would also like you to tell me your story of entering and living in your retirement years, including all the events and experiences which were important for you. Start wherever you like". Once informants finished their stories, follow-up questions were used to elicit further detail within the first interview, and in the subsequent second interview.

\section{Analysis and interpretation}

A critical approach to narrative analysis was employed with the aim to examine how individuals' accounts of how they came to be retired reflected complex ways occupations are negotiated within broader discourses. According to Hardin ${ }^{44}$, this requires reading between the language of personal narratives and broader discourses to move between individual and sociocultural levels. As well, given the multiplicity of discourses individuals may negotiate, for example, in relation to age, gender, social class and other social positions, Hardin also suggests that it is necessary, within a particular analysis, to strategically temporarily fix a set of meanings and analyse how these meanings are contextually deployed ${ }^{44}$. Thus, 
I strategically focused on how subjects positioned themselves in relation to age.

The process involved whole text and line-by-line reading of summary narratives as well as original transcripts. Subsequently, segments in which informants' talk focused on how, why and when they came to retire was marked. These segments were first coded in an open-ended manner (e.g. retirement as desired, no option to work, decreasing effectiveness). A second level of coding explicitly focused on how individuals attended to age.

\section{FINDINGS}

Overall, findings indicated that ageism mattered for how and when individuals came to retire, how they viewed their occupational possibilities, and what occupational possibilities for work where supported by social relations, practices and systems. Many informants conveyed experiences of being marginalised, displaced and disempowered in the work force prior to retiring, and connected these, sometimes explicitly but often implicitly, to ageist discourses, practices and relations. In addition, some informants internalised ageist discourses such that they framed their changed position and capabilities in relation to work as a 'natural' part of the ageing process. Within the following sections, three narrative exemplars (identified using pseudonyms) are presented to illustrate various ways ageist discourses, relations, practices and systems shaped occupational possibilities and bounded choices regarding retirement. These exemplars were chosen in order to provide a detailed, contextualised presentation of the narrative data, but are reflective of tensions related to age that pervaded various narratives.

Robert: Marginalised and displaced - "I realised that I'm ultimately now on the shelf..."

Robert's narrative conveys the story of a failed attempt of a man who was facing mandatory retirement to extend his work life, and thus expand his occupational possibilities. Robert, who was 79 and had been retired some 15 years at the time of the study, described his departure from the workforce as unwanted, bitter and disappointing.

Robert had worked in a human resources department for some 15 years. He explained that at age 64 , as he was approaching the age of mandatory retirement, he did not feel ready to retire as he "didn't feel old" and also because,

"I still have something to offer... And I could see the results of what I was doing. I could, I was making a difference".

Robert explained the irony of the situation he faced as he approached the age of 65 , as he was the person who, in his younger years, had come up with the idea to enact mandatory retirement in his workplace,

"As I realised...that I was going to have to retire at age 65. At that time we had a mandatory retirement policy. And interesting enough it was a policy which I brought in".

Consistent with ageist beliefs, Robert explained that he and his co-workers had established a mandatory retirement policy as a way to get rid of older workers who they viewed as inefficient and resistant to leave,

"We brought it in because there were some old people working in the organisation that we wanted to go. These were very well respected people, they were not particularly efficient at what they were doing but they were highly regarded. And nobody was going to go."

Contrary to this negative image of older workers, Robert emphasised that he, at age 64, was "making some waves" and "making a contribution."

Being the manager of the human resources department, Robert explained that he had the power to negotiate a part-time contract position and framed himself as proactively setting up this opportunity,

"And so I came up with the idea well I'm 64-ish... I could eliminate my position and come back and work part-time. I could act as a kind of consultant in the department".
However, Robert's attempt to continue to be productive through paid labor did not unfold as expected, nor did it result in the positive outcomes he imagined.

Robert's narrative reveals limits of contingent work for ageing workers arising out of ageist workplace relations and practices that result in marginalisation and displacement. He described that during his 6 month part-time, contract position, he began to feel he was "on the shelf",

"During the time that I had gone part-time, and we ended up appointing somebody else to be the manager...I realised that I'm now ultimately on the shelf. People are not going to be asking (him for advice or input)."

Robert emphasised the implicit nature of the ageism he faced indicating that,

"Nothing was said to me but l'm sure of it. And I don't think it was an unpleasant attitude, it was just the way it is and... well what can you do about it".

Although Robert emphasized that people did not have personal "antagonism towards me", he also described 'sensing' that younger co-workers were hoping he would leave,

"I sensed there was a feeling that well the sooner he goes, the better. When he's working part time that's a step in the right direction. But when he goes that'll be good."

In an explicit way, Robert attributed the changed relations in his workplace to differences in power related to age, drawing parallels between how he had perceived older workers and how his co-workers perceived him,

"But rather as you get older, like it or not...people are going to think, well if we could move him away somewhere we could do things differently. Or, we could do things differently by being very hard and simply saying, buddy your time is up. But we don't want to do that, and so what was happening to me was the same kind of thing that I had been turned on to somebody else, in a sense, many years ago".

Ultimately, Robert described these ageist practices and social relations as "just the way it is", pointing to the implicit ways that aging workers are made to feel like they do not belong,

"It was just the way it is ...And so they took the opportunity... give me some work but pretty insignificant stuff... I began to feel for the first time at work, insignificant...So I began to get the message and began to realise this is what happens".

In the end, against his wishes, Robert's contract was not renewed. His narrative highlights the loss of power in the workplace that can accompany a shift to a part-time contract as one ages, which is ironically a strategy often promoted within contemporary policy aimed at promoting 'productive' aging ${ }^{27,42}$.

In summary, this exemplar displays how ageist workplace practices and workplace relations meant that this individual could not succeed in achieving his desired outcome of continued work. Rather than achieving social inclusion, a sense of continued contribution or the enhanced well-being he felt continued work would allow, Robert described feeling that he was "ultimately on the shelf".

Marjorie: Marginalised and disempowered - "(I) could stay longer (at work), I would (have). And then...it never came to that"

In contrast to Robert, Marjorie, who had worked in a factory, was female, and was only a high school graduate, did not have the power to alter her job as she aged. Marjorie, who was 72 at the time of being interviewed, had worked in a factory for 32 years doing production line and repair work. She conveyed that she "loved her job" and that her plan, given she would be eligible for a full company pension, had been to retire at "60, my normal retirement age". She emphasized that if the work had remained enjoyable and available she "probably would have worked until I was 65" and she "could have stay(ed) longer" but "it never came to that". Given that her company's approach to re-structuring during recessionary times aimed to "get rid of the old people", Marjorie indicates she chose to retire at age 57 , by her "free will", when offered a retirement incentive package even though her pension "payments were lower than if I would 
retire with 60". At the time of the interview, Marjorie continued to convey her story of coming to retire with anger, emphasising that her employer "made us (older workers) feel guilty to stay, that's what made me mad".

Marjorie began her story by conveying how her employer made her job more difficult for her to do as she aged. For example, although she had worked day shifts from some 17 years, she was displaced in her later years to shift work,

"I worked for I6 or I 7 years, I worked on days....some departments were closed down but other ones opened. So you had to apply for another job....it put me first in two shifts, then it put me in three shifts... And that's actually why I retired earlier, because I had enough of 3 shifts".

Marjorie described how the shift work became more tiring, and did not fit well with her relationship with her husband,

"It was just tiring coming home in the middle of the night. And my husband didn't like it... He didn't like sitting in the afternoon by himself, when he'd come home from work...Or...you had to go at II o'clock at night, you had to go to work and you come home in the morning and he was gone, and that was one of the reasons".

She also conveyed, with resentment, how her employers used intimidation, along with a "buy out" package "to get rid of the old people" and "tried to bully them". Marjorie emphasised that she understood the economic reasons for her employer's actions, but resented that the employer assumed older people could and should retire,

" They called the whole factory together ... they said ... people who had the years of 85 (a sum of chronological age and years of service) they should retire, in a way, they forced us ... And they were saying, if we don't retire they have to lay off so many people and actually I was kind of mad at the time ... in a way, they made us feel guilty not to take retirement and you know leave the space for the young ones, they gave us the run around. ...It was my choice, but you just don't put people in that predicament".

Marjorie also emphasised that the employer's approach changed age relations in the workplace, leading to tensions that made continuing to work even less possible,

"Because then those young kids which work there, naturally they would then lose their job, and called us, you won't believe what, from old bags and all that stuff".

Given that such buy-out packages are a common, taken-forgranted labour force management strategy in the North American context ${ }^{27}$, Marjorie's narrative highlights how this taken-for-granted practice can be enacted and experienced in ways that perpetuate ageist beliefs and discriminatory practices and bound occupational possibilities for ageing workers. In summary, Marjorie's narrative conveys ways workplace practices, based in ageist assumptions and discriminatory behaviours, can be structured to make work increasingly untenable and shut down occupational possibilities for continued dignified, meaningful work. In addition, Marjorie's narrative explicitly attends to how ageist social relations can make continued work untenable.

Maurice: Internalised ageism and identity degradation - "As I get older I find it (change) difficult too"

Older workers can hold ageist views regarding their own productivity that, in turn, conceal underlying structural reasons for work difficulties ${ }^{27}$. Maurice's narrative conveys how such identity degradation can occur through a process in which ageing workers, within an ageist labour market in which ageing workers tend to experience prolonged duration of unemployment ${ }^{45,46}$, may need to take on work for financial reasons that does not draw upon the skills, knowledge and experiences they have developed over their lifetimes.

Maurice, 67 years old at the time of the narrative interviews, had retired 6 years before. Maurice provided a detailed description of his career path, emphasising success and progress. After being a hospital pharmacist, he completed graduate school in health care administration. He subsequently held a variety of administrative positions in which he described himself as a "change agent". Overall, Maurice constructed himself as an accomplished administrator who had been a key part of significant health care reforms, and who had consistently found "joy" and "fun" in his work,

"I was appointed an Executive Director for the $X$ (specific name) Health Council ... And, again it was fun, because it was community, and I worked a lot with hospitals and ... we were making progress".

Maurice's last full-time job was as an Executive Director in a hospital during a time of recession,

"See at the time they were cutting a lot of budgets in the hospital field, and (as a) small hospital and all the staff is entrenched ... I loved the place and I loved the people, but because of the pressures I was forced to cut budgets and reduce staff".

Maurice stayed in this job for "II years, almost 12 years", but retrospectively felt he "overstayed himself". He indicated he was pressured to leave,

'And I was pressured ... why don't you leave? Don't you want to go someplace else? And I says, 'no, I want to finish this'. I'm not sure I made the right decision".

Eventually, Maurice was fired, an event he describes as both inevitable and painful,

"And finally ... they came to me and said, we can't keep you. It's time for you to go...I was fired and...I knew it was coming. But you know what? Even though you know it's coming it still hurts".

Being fired from this position was a crucial point in Maurice's career and narrative. He found out, similar to many of his colleagues of a comparable age, that he was unable to get a permanent job position at an equivalent pay and status level. Given his financial needs, Maurice took an offer to manage a small company, one that he had previously contracted services to when he was an Executive Director, even though it was lower status and pay,

"I had hired them to run maintenance and housekeeping in a department in the hospital, they had a management service branch. And they offered me a job. It was a lot less money but I took it. I mean, I said, what am I going to do? Wait around and mope?"

Within this work, Maurice indicates "it wasn't joy any more, it was becoming more of a chore." When describing how he came to retire, he framed himself as increasingly less motivated as well as less capable of analysing and responding to problems. Internalising stereotypes regarding the declining abilities of ageing workers, he attributed these changes not to being demoted or more restricted in his work but rather to ageing and his "point in life",

"I enjoy my work and what I did in my career ... I was getting to the point where it wasn't fun anymore. That was a big driving force ... you know you reach a point in your life where you say, l've already seen that issue ... I was at the point where I didn't see the differences anymore ...you don't search enough to see the differences and that needs fresh ears... I think you lose your effectiveness when you don't see the difference".

Ultimately Maurice framed himself as finding change difficult "as I got older", and as no longer able to be a change agent at work,

"I always prided myself in being a change agent... I reached the point where I was no longer the change agent".

As such, Maurice's narrative displays how ageism can be internalised in ways that lead to ageing workers individualising their changed relation to work, rather than questioning how restricted work possibilities serve to marginalise them from opportunities for meaningful work that draws upon their skills, knowledge and experience.

\section{DISCUSSION}

The 2006 World Federation of Occupational Therapists Position Statement on Human Rights clearly articulated the responsibility of occupational therapy to address occupation as a human right ${ }^{21}$ To fully enact this responsibility, occupational therapists need to 
be politically aware of the power relations and processes through which occupational injustices are created and sustained ${ }^{10,15}$. This article seeks to raise awareness of how social relations of power related to age can be enacted in implicit and explicit ways that influence occupational possibilities for work, bound retirement 'choices', and impact on how this occupational transition is experienced and storied. Moreover, the article provides an example of a methodological approach that can be taken up to enhance awareness of how power relations, embedded in discourses, structures and systems, shape how individuals understand and negotiate occupational possibilities.

The aim of critical narrative work is not to seek generalisable understandings of linkages between discourses and narratives, but to gain insight into what is possible and intelligible in a specific context and to stimulate dialogue and action related to social change $\mathrm{e}^{47}$. Thus, it is not claimed that this study presents an exhaustive understanding of how ageism shapes occupational possibilities and occupational 'choices' in the work to retirement transition, and the contextual situatedness of the findings is acknowledged. What this study adds to existing research on 'occupation as situated' is an examination of how occupational possibilities for continued work and 'choices' to retire are shaped within contexts imbued with ageism. For example, the narratives demonstrate how practices and relations, based within ageist beliefs about aging workers and ageist assumptions that privilege the right to work for younger workers over that of older workers, can shut down possibilities for continued work as well as create conditions that lead to work becoming less meaningful, engaging and financially beneficial.

Given that the informants in this study discussed workplaces practices commonly taken up to manage ageing workforces in Canada and other OECD member countries and age-based social relations that have been found to exist by other researchers ${ }^{27,48}$, further consideration of how ageism is taken up in relations of power in ways that marginalise, displace and disempower ageing workers seems warranted. Indeed, such research is of particular contemporary relevance given that discourses of productive ageing, which promote paid work as the ideal means for ageing citizens to enact their citizenship responsibilities, are increasingly fore-fronted within international policy directives as well as policies within many members' countries of the OECD ${ }^{35}$. In line with neoliberal rationality, such policy directives often place the responsibility for continued work onto ageing individuals, neglecting differential access amongst ageing persons to 'choices' to work as well as ways in which ageist ideologies and practices bound occupational possibilities ${ }^{49,50,51}$. The neglect of these complexities may increasingly marginalise those ageing workers who need to work into low paying, insecure forms of work, further shaping occupational inequities between younger and older workers and amongst older workers. Moreover, this individualisation of responsibility obscures the role of employers, markets and governments in shaping possibilities.

Given occupational therapy's commitment to address abuses of the right to occupation, there is a need for occupation-focused research and practice to critically question and work against ageist beliefs, relations, practices, systems and structures that constrain the right to work. In addition, to guard against policy directions that forefront productive activity as the primary means to achieve 'ageing well' and obscure the occupational needs of older adults who may no longer wish to or be capable of engaging in work ${ }^{35,42,48}$, occupational therapists and scientists have a role to play in ensuring that contextual conditions provide possibilities for older citizens to participate in a diversity of occupations that enable them to live dignified, meaningful lives. Although issues fore fronted within gerontological discourse and studies in Africa are certainly divergent from issues of 'productive ageing' and the retreat of the welfare state from retirement, there have been calls for scholarship attending to how political, economic and social transformations are shaping meanings of ageing and how ageing citizens experience and orchestrate daily life ${ }^{52}$. Narrative inquiry informed by a critical occupational perspective can make a valuable contribution to such scholarship, addressing the call to link individual experiences and social forces and focus "... on the concept of social change as an important framework for understanding ageing in Africa past, present and future"34:110.

More broadly, these findings add to the recent body of work that has de-stabilised the assumption of occupational choice as an individualised phenomenon ${ }^{3,12,23}$. A common feature of this body of work has been to show how occupational choice, or agency in relation to occupation, is 'bounded' within various layers and aspects of contexts. Linking this with transformative occupational therapy practice, this notion of 'bounded agency's! further supports the growing call to develop and enact approaches to practice that refuse to adopt an individualistic orientation and that collaboratively work with individuals and collectives to understand and change the relations of power that bound their occupational possibilities in unjust ways $s^{3,10,22,23}$.

Methodologically, this study provides an illustration of the potential contributions of occupation-based research that situates the talk of individuals and collectives within power relations through linking narratives and discourses. Such an approach responds to the identified need for the fostering of political consciousness as it can enable occupational therapists and scientists to become more "... acutely aware of the context in which claims about how one ought to live are advanced"53:200. Moreover, given that many contemporary discourses, aligned with a neoliberal agenda to 'activate' collectives at risk of 'dependency' on the state, shape and circulate messages that address what occupations individuals and groups should and should not do, it is imperative that knowledge generation and practice aimed at enabling occupation pay close attention to the interplay between discourses and occupational possibilities.

At the same time, the approach used in this study was limited in its attention to only age. Intersectionality theory has highlighted the need to attend to the complexity of intersections of race, age, gender, citizenship status, geographical location, sexuality and other attributes in understanding how the lives of individuals and collectives are governed and experienced ${ }^{28}$. This is a key theoretical, and methodological, challenge facing occupational scientists and therapists committed to transforming socio-political practices, systems and structures. As well, it is acknowledged that findings of critical narrative work are contextually specific, but that the insights regarding how power operates via discursive means have analytical utility beyond the context in which a particular study is conducted ${ }^{44}$.

\section{CONCLUSION}

This study is located within the emerging critically-informed body of occupation-focused research attending to the political nature of occupation, a body of work that is both expanding understanding of situated nature of action and informing practice aimed at addressing occupational injustices. Within both occupational science and occupational therapy, there have been increasing calls for research and practice to commit to social transformation that addresses the right of all humans to engage in occupations that enable them 'to flourish, fulfil their potential and experience satisfaction in a way consistent with their culture and beliefs ${ }^{\prime 21}$. As well, there is a parallel recognition that enacting social transformation requires addressing how inequities and injustices are politically and socially produced ${ }^{18}$. Given this shared commitment and recognition, the time seems ripe to move beyond debating the legitimate place for theorising occupation or attempting to define the boundary between occupational therapy and occupational science to build from these synergies to collaboratively inform and enact such social transformation.

\section{REFERENCES}

I. Asaba, E., Jackson, J. Social ideologies embedded in everyday life: A narrative analysis about disability, identity and occupation. Journal of Occupational Science, 201 I; 18:139-152.

2. Dickie, V., Cutchin, M., Humphry, R. Occupation as a transactional experience: A critique of individualism in occupational science. Journal of Occupational Science, 2006; 13: 83-93.

3. Galvaan, R. Occupational choice: The significance of socio-economic and political factors. In: Whiteford, GE, Hocking, C, editors. Occupational science: Society, inclusion and participation. West Sussex, 
UK: Wiley-Blackwell, 2012: I52-162.

4. Laliberte Rudman, D. Governing through occupation: Shaping expectations and possibilities. In: Whiteford, GE, Hocking, C, editors. Occupational science: Society, inclusion and participation. West Sussex, UK: Wiley-Blackwell, 2012:100-1 I6.

5. Phelan, S., \& Kinsella, E. A.. Occupational identity: Engaging sociocultural perspectives. Journal of Occupational Science, 2009; 16(2): 85-91.

6. Pollard, N., Kronenberg, F., Sakellariou, D. A political practice of occupational therapy. In Pollard, N., Sakellariou, D., Kronenberg, F., editors. The political practice of occupational therapy. London, UK: Churchill Livingstone. 2009: 3-20.

7. Townsend, E., \& Wilcock, AA. Occupational justice and client-centred practice: A dialogue in progress. Canadian Journal of Occupational Therapy. 2004; 7I: 75-87.

8. Angell, AM. Occupational-centred analysis of social difference: Contributions to a socially responsive occupational science. Journal of Occupational Science, 2012; (ahead-of-print).

9. Kiepek, N., Phelan, SK., Magalhaes, L. Introducing a critical analysis of the figured world of occupation. Journal of Occupational Science. 2013; (ahead-of-print).

10. Galheigo, SM(20II). What needs to be done? Occupational therapy responsibilities and challenges regarding human rights. Australian lournal of Occupational Therapy, 201 I; 58: 60-66.

II. Aldrich, R., Marterella, A. (2012). Community-engaged research: A path for occupational science in the changing university landscape. Journal of Occupational Science, 2012; (ahead-of-print).

12. Beagan, BL, Etowa, J. The impact of everyday racism on the occupations of African Canadian women. Canadian Journal of Occupational Therapy, 2009; 76: 285-293.

13. Maghalhães, L. What would Paulo Freire think of occupational science? In: Whiteford, GE, Hocking, C, editors. Occupational science: Society, inclusion and participation. West Sussex, UK: WileyBlackwell, 2012:8-19.

14. Njelesani, J., Gibson, BE, Nixon, S., Cameron, D., Polatajko, H. Toward a critical occupational approach to research. International Journal of Qualitative Methods, 2013: 207-220.

15. Kronenberg, F., Pollard, N. Political dimensions of occupation and the roles of occupational therapy. The American Journal of Occupational Therapy, 2006; 60: 617-626.

16. Hocking, C., Whiteford, EA. Introduction to critical perspectives in occupational science. In: Whiteford, GE, Hocking, C, editors. Occupational science: Society, inclusion and participation. West Sussex, UK: Wiley-Blackwell, 2012: 3-7.

17. Frank, G. 2010 Ruth Zemke Lectureship. Occupational therapy/ occupational science/occupational justice: Moral commitments and global assemblages. Journal of Occupational Science, 2012, 19: 25-35.

18. Laliberte Rudman, D. 2013 Ruth Zemke Lectureship. Embracing and enacting an 'occupational imagination': Occupational Science as transformative. Journal of Occupational Science, 20 I 4; 20: 298-3 I 3.

19. Pollard, N., Sakellariou, D., Kronenberg, F. Political competence in occupational therapy. In: Pollard, N., Sakellarious, D., Kronenberg, F., editors. A political practice of occupational therapy. Edinburgh: Churchill Livingstone. 2009: 21 -38.

20. Nilsson, I., \& Townsend, E. Occupational justice-bridging theory and practice. Scandinavian Journal of Occupational Therapy, 2010; 17: 57-63.

21. World Federation of Occupational Therapists. Position statement. Human rights. Australia: WFOT, 2006.

22. Ramugondo, EL, Kronenberg, F. Explaining collective occupations from a human relations perspective: Bridging the individual-collective dichotomy. Journal of Occupational Science, 201 3; (ahead-of-print).

23. 23. Ramugondo, EL. Intergenerational play within family: The case for occupational consciousness. Journal of Occupational Science, 2012; 19: 326-340.

24. 24. Aldrich, RM, Dickie, VA. "It's hard to plan your day when you have no money": Discouraged workers' occupational possibilities and the need to reconceptualize routine. Work: A Journal of Prevention, Assessment and Rehabilitation, 2013; 45: 5-I5.

25. Huot, S. Francophone immigrant integration and neoliberal governance: The paradoxical role of community organizations. Journal of Occupational Science, 2013; 20: 326-34l.

26. Butler, R. Age-ism: Another form of bigotry. Gerontologist, 1989; 9: 243-246.

27. McMullin, J., Marshall, V. Ageism, age relations and garment industry work in Montreal. Gerontologist, 200 I; 4I: I I I-I 22.

28. Calasanti, T. Ageism, gravity and gender: Experiences of aging bodies. Generations, 2005; Fal: 8- 12.

29. Bytheway, B. Ageism and age categorization. Journal of Social Issues, 2005; 61: 36I-374.

30. Andersen, KA, Richardson, VE, Fields, NL, Harootyan, RA. Inclusion of exclusion? Exploring barriers to employment for low-income older adults. Journal of Gerontological Social Work, 2013; 56: 318-334.

31. Malinen, S., Johnston, L. Workplace ageism: Discovering hidden bias. Experimental Aging Research, 2013; 39: 445-465.

32. Angus, J., Reeve, P. Ageism: A threat to 'ageing well' in the $21^{\text {st }}$ century. The Journal of Applied Gerontology, 2006; 25: I37-I 52.

33. Laliberte Rudman, D. Occupational possibilities. Journal of Occupational Science, 2010; 17: 55-59.

34. King, S.V. Introduction to the Journal of Cross-Cultural Gerontology, Special issue on aging and social change in Africa. Journal of CrossCultural Gerontology, 2008; 23: 107-I I0.

35. Powell, J.L. The power of global aging. Ageing International, 2010; 35: $1-14$.

36. Moulaert, T., Biggs, S. International and European policy on work and retirement: Reinventing critical perspectives on active ageing and mature subjectivity. Human Relations. 2013; 66: 23-43.

37. Kemp, C.L.. Denton, M. The allocation of responsibility for later life: Canadian reflections on the roles of individuals, governments, employers and families. Ageing \& Society, 2003; 23: 737-760.

38. McDonald, L., Donahue, P. Retirement lost? Canadian Journal on Aging, 201 I, 30: 401-422.

39. Rose, N. Powers of freedom: Reframing political thought. University of Cambridge, 1999.

40. Laliberte Rudman, D. Shaping the active, autonomous and responsible modern retiree: An analysis of discursive technologies and their connections with neoliberal political rationality. Ageing and Society, 2006; 26: 181-201

4I. Laliberte Rudman, D. (2006). 'Positive aging' and its implications for occupational possibilities in later life. Canadian Journal of Occupational Therapy, 2006, 73: 188-192.

42. Laliberte Rudman, D., Molke, D. Forever productive: The discursive shaping of later life workers in contemporary Canadian newspapers. Work, 2009; 32:377-389.

43. Ainsworth, S., Hardy, C. Discourse and identities. In: Grant, D., Hardy, C, Oswick, C., Putnam, L., editors. The Sage handbook of organizational discourse. Thousand Oaks, California: Sage, 2004: 153- 174

44. Hardin, PK. Theory and language: locating agency between free will and discursive marionettes. Nursing Inquiry, 200 I; 8: I I- I8.

45. Auer, P., \& Cazes, S. The resilience of the long-term employment relationship: Evidence from the industrialized countries. International Labour Review, 2000; 139: 379-408.

46. Gunderson, M. Age discrimination in employment. Contemporary Economic Policy, 2003; 21 : 318-328.

47. Chase, SE. Narrative inquiry: Multiple lenses, approaches, voices. In Denzin, N., Lincoln, Y. Lincoln, editors. The Sage handbook of qualitative research. Thousand Oaks: Sage. 2005: 65I-679.

48. Mann, K. Activation, retirement planning and restraining the "third age'. Social Policy \& Society, 2007; 6: 279-292.

49. Cooper, M. The inequality of security: Winners and losers in the risk society. Human Relations, 2008; 61: I229-1 258.

50. Laliberte Rudman, D. 2012 Townsend \& Polatajko lectureship. Enacting the critical potential of occupational science: Problematizing the 'individualizing of occupation'. Journal of Occupational Science, 20I3; 20: 298-313.

51. Vickerstaff, S.,Cox, J., Retirement and risk: the individualization of retirement experiences?", The Sociological Review, 2005: 77-95.

52. Makoni, S. (2008). Aging in Africa: A critical review. Journal of CrossCultural Gerontology, 2008; 23: 199-209.

53. Minkler, M., Holstein, MB. From civil rights to... civic engagement? Concerns of two older critical gerontologists about a "new social movement" and what it portends. Journal of Aging Studies, 2008; 22: 196-204.

http://dx.doi.org/ 10.17 I59/23 I 0-3833/20 I 5/v45nola5

Corresponding Author

Debbie Rudman

drudman@uwo.ca 